\title{
KLASİK TÜRK EDEBIYYATI ARAŞTIRMA YÖNTEMLERİ(I-II), SELAMİ ECE, ESER YAYINLARI, ERZURUM, 2015
}

\section{Hayriye DURKAYA*}

Başarılı ve faydalı bir çalışma ortaya koyabilmek hangi disiplin sahasında olursa olsun sitemli ve düzenli bir çabayı gerektirir. Araştırmacı için çalışacağı konuyu belirlemek tez yazma yolunda atılacak ilk adımdır. Ancak hedefi belli ama gittiği yol hakkında bilgisi olmayan bir sürücü için hata ve kaza nasıl kaçınılmazsa araştırmacı için de benzer durumlar söz konusu olabilir. O halde, araştırmacının konuyu belirledikten sonra yapması gereken ilk şey, bulunduğu disiplinin yöntem ve kurallarını öğrenerek yola koyulmasıdır.

Klasik Türk edebiyatı sahası araştırmacılarının soru ve sorunlarına cevap bulabilmesi için çalışmanın ilki, 2007 yılında “Klasik Türk Edebiyatı Araştırma Yöntemleri”yle yayınlanmış olup ardından 2015 senesinde aynı kitap daha da genişletilerek "Klasik Türk Edebiyatı Araştırma Yöntemleri (I-II)" adıyla okuyucuyla buluşmuştur.

On iki bölümden oluşan eserin ilk bölümünde, ilmin önemi ve kutsallığından bahsedilerek öğrenmenin önemini vurgulayan yaşanmış hikâyelerden örnekler verilmiştir. Bir bilimsel eserde bulunması gereken etik ve hukuki özellikler açıklanmıştır. Araştırmacı ve danışmanın sahip olması gereken özellikler aktarılmış ve araştırmacı ile danışmanı analiz eden iki mini ankete yer verilmiştir. İlk bölümün son başlıkları tez yazmaya hazırlanan araştırmacının dikkat etmesi gereken hususlara ayrılmıştır.

Kitabın ikinci bölümü, daha çok klasik edebiyat araştırmacılarını ilgilendirecek genel bir literatür taramasıdır. Arap, Fars ve Türk edebiyatı ile ilgili temel kaynakların künyesi verilerek kaynaklar hakkında kısaca bilgi verilmiştir. “Alan Araştırması Literatürü” başlığı içerisinde tezkireler, biyografik eserler, ansiklopediler, edebiyat tarihleri, sözlükler, yazma ve matbu eser katalogları, bilgisayar üzerinden ulaşılabilecek veri tabanları gibi tez yazım aşamasında lazım olabilecek birçok kaynak paylaşılmıştır.

Nüsha tavsifinin doğru yapılması ve herkes tarafından anlaşılabilmesi için ortak terimlere ihtiyaç vardır. Bu duruma istinaden kitabın üçüncü bölümü nüsha tavsifine ayrılmıştır. Araştırmacının karşılaşabileceği terimler alfabetik sırayla başlıklandırılmış ve bazı başlıklar

\footnotetext{
* Arş. Gör.; Atatürk Üniversitesi Edebiyat Fakültesi Türk Dili ve Edebiyatı Bölümü, h.durkaya@atauni.edu.tr.
} 
$\underline{648^{*} \text { TAED }} 55$ Hayriye DURKAYA

görsel ögelerle desteklenmiştir. Verilen örneklerin renkli ve zengin olması kavramları araştırmacının zihninde somutlaştırmıştır.

Yazma eser çalışan araştırmacının tavsif aşamasında yapması gerekenlerden biri de okuduğu metnin hangi yazı çeşidi ile yazıldığını belirlemektir. Tabii ki bunu yapabilmesi için yazı türlerini bilmesi ve tanıması gerekir. Bu problemi gidermek adına, yazar dördüncü bölümü "Hat(yazı) ve Yazma Eser" başlığına ayırmıştır. Bu bölümde, aklam-1 sitte ile diğer yazı türleri farklı farklı metinlerden alınan örnek metinlerle anlatılmış ve verilen örnek metinler Latin harflerine aktarılmıştır.

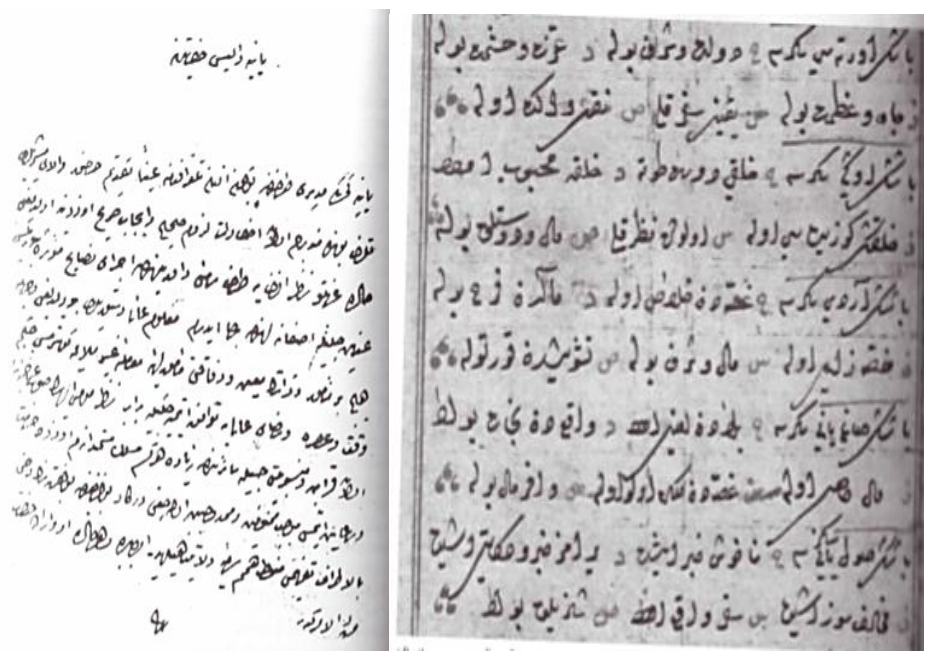

Foto 1: Kitapta yer alan el yazması metinlerden örnekler

Beşinci bölüm "Yazma Eser Kayıtları ve Mühürler” başlığıdır. Bu bölümde, mühürler hakkında örneklerle bilgi verilmiş; eserin hangi tarihte ve nerede yazıldığı hakkında bize ipucu verecek olan yazma eser kayıtlarına değinilmiştir. Yazmanın bir bakıma elden ele olan yolculuğu hakkında malumat veren bu kayıtlar, metnin müellife mi müstensihe mi ait olduğunu gösterebilir.

Altıncı bölüm "Tarih ve Takvim" konusuna ayrılmıştır. Klasik edebiyatta şairler hüner göstermek maksadıyla ebced hesabını kullanarak sünnet, düğün, sefer, yangın, saray, çeşme yapımı gibi birçok olaya tarih düşmüşlerdir. Bu bölümde, tarih düşürme çeşitleri beyitlerle anlatılmış; hicri tarihin miladi, miladi tarihin hicri takvime nasıl dönüştürüleceği formülleştirilmiştir.

Yedinci bölüm, "Metin Tespiti” başlı̆̆ını taşır. Yazma eser üzerine çalışan araştırmacı okuduğu metnin dönem ve gramatikal özelliklerini göz önünde bulundurmalıdır. Bu kısımın ilk 
iki başlığı manzum ve mensur metinlerin dil özellikleri ile ilgili olup imla hakkında detaylı bilgi verilmiştir. Yazmalarda geçebilecek kalıplaşmış ifadeler ile homografik kelimeler alfabetik olarak sıralanmıştır. Araştırmacının metin içerisinde karşısına çıkabilecek kısaltmalar ve işaretler hakkında bilgi verilmiştir.

Sekizinci bölüm “Metin Transkripsiyonu”, dokuzuncu bölüm "Metin Neşri”yle ilgilidir. $\mathrm{Bu}$ bölümlerde bir çeşit kodlama sistemi olan transkripsiyondan ve metin neşri çeşitleri anlatılmıştır.

Onuncu bölüm "Metin Tenkidi”dir. Tenkit ve eleştiri mefhumları üzerinde durulmuş, metin tenkidine ilk nerede ve hangi sebeplerden ötürü başvurulduğu izah edilmiştir. Metin tenkidinin ilk aşaması olan nüsha değerlendirmesinin nasıl yapılması gerektiği şablonlarla anlatılmıştır. Farklı araştırmacıların yaptığı metin tenkitlerinden örnekler sunulmuştur.

Son bölüm alana vakıf olan birinin yapabileceği "Metin Tamiri" ile ilgilidir. Metin tamiri yapacak araştırmacının gerekli donanına sahip olması lazımdır. Yazar, bu konu ile ilgili dikkate değer yöntem ve örnekler vermiştir. Tamir yapılmasını gerektirecek durumlar sıralanmış, alternatif çözümler sunulmuştur.(Mesela vezne uyması için kalemle yazılmış olan bir kelimeyi kalem ile okumak gibi.)

Eser, kaynakça ile şahıs ve yer adlarına göre tasnif edilmiş fonksiyonel bir dizinle bitmektedir. Yazar Ece, kitabın anlam ve önemine uygun olarak kitabın en sonuna kendi temmet kaydını düşmüştür.

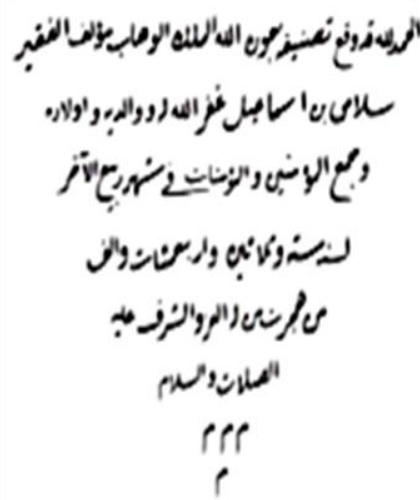

Son olarak araştırmacıların her zaman ihtiyaç duyabileceği bu eseri bilim dünyasına kazandıran Prof. Dr. Selami ECE hocamıza titiz çalışmasından dolayı teşekkür ederiz. 